\title{
Mesoproterozoic Calymmian Tintinnids from Central China
}

\author{
You-Xing Li ${ }^{*}, 1$, Su-Xin Zhang ${ }^{2}$ and Jie Zhang ${ }^{3}$ \\ ${ }^{I}$ Key Laboratory of Biogeology and Environmental Geology, Ministry of Education, China University of Geosciences, \\ Wuhan Institute of Technology, Wuhan 430073, China \\ ${ }^{2}$ State Key Laboratory of Geological Processes and Mineral Resouces, China University of Geosciences, Wuhan \\ 430074, China \\ ${ }^{3}$ Hangzhou Institute of Petroleum Geology, Hangzhou 310023, China
}

\begin{abstract}
Tintinnids are very common in all marine water and even fresh water. The oldest fossils of Tintinnids are not only appeared in Neoproterozoic Era, but also in Mesoproterozoic Calymmian. Eight species of six genera Tintinnids of Mesoproterozoic Calymmian, from Huangmailing Phosphoric Ore in Hubei Province of Central China, are illustrated in this paper. They are the oldest ancestor of Tintinnids. Tintinnids had about 1600 million years history.
\end{abstract}

Keywords: Titinnids, Mesoproterozoic, Calymmian, Central China.

Tintinnids are important members of the plankton in all marine habitats, and some of them also can live in the fresh water nowadays [1-13]. But very few of them had been preserved as fossils in the rocks. The fossils of Tintinnids had been reported by paleontologists that was appeared as early as the Neoproterozoic Era and were very common in Late Jurassic and Early Cretaceous Period [14-17]. In 2006, we reported that Funnela sinensis [18], the oldest fossil of Tintinnids in the rocks of the lower part of Huangmailing Formation of Mesoproterozoic (about 1600 million years ago). Here, the aim of this study is to report on the Tintinnids more detail in the metamorphic rocks of Huangmailing Formation from Huangmailing phosphoric Ore in Hubei Province of Central China. Eight species of Tintinnids are illustrated with scanning electron micrographs here. Tintinnids samples for species identification were collected from the metamorphic rocks of the seven Geological Sections of Huangmailing Phosphoric Ore: the fourth bed of granulitite and the fifth bed of granulitic apatitolite of Section A; the fifth bed of granulitite and the sixth bed of granulitic apatitolite of Section B; the fourth bed of leucoleptite, the seventh bed of granulitite, the ninth bed of granulitite and the eleventh bed of gneiss of Section D; the first bed of leucoleptite of Section E; the first bed of granulitite, the sixth bed of granulitic apatitolite and the seventh bed of leucoleptic apatitolite of Section F; the fourth bed of leucoleptite, the sixth bed of leucoleptic apatitolite, the eighth bed of leucoleptic apatitolite and the ninth bed of granulitic apatitolite of Section G; and the third bed of leucoleptite and the fourth bed of leucoleptic apatitolite of Section H (Fig. 1).

*Address correspondence to this author at the Key Laboratory of Biogeology and Environmental Geology, Ministry of Education, China University of Geosciences, Wuhan Institute of Technology, Wuhan 430073, China;

E-mail: youxingli@hotmail.com

\section{GEOLOGICAL SECTION OF HUANGMAILING PHOSPHORIC ORE}

\section{Huangmailing Formation}

\section{Section G}

Section $G$ is the main section which yielding a lot of fossils. It is located at Dajian hill.

Bed 12 2.5m. Dark grey granulitite, yielding Tubular fossils.

Bed $11 \quad 2.2 \mathrm{~m}$. Black granulitite, yielding Tintinnids Eutintinnus tubulosus, E. frakmoi and Tubular fossils.

Bed $10 \quad 1.3 \mathrm{~m}$. Striped granulitite, yielding Tubular fossils.

Bed $92.3 \mathrm{~m}$. Dark grey granulitic aputitolite, yielding Tintinnids Eutintinnus tubulosus, Funnela sinensis, Salpingella acuminata, Undella bicollaria and Tubular fossils.

Bed $8 \quad 2.1 \mathrm{~m}$. Grey leucoleptite, yielding Tubular fossils.

Bed $7 \quad 0.8 \mathrm{~m}$. Black grey leucoleptic apatitolite, yielding Tubular fossils.

Bed $6 \quad 2.0 \mathrm{~m}$. Dark grey granulitite, yielding Tubular fossils.

Bed $5 \quad 0.4 \mathrm{~m}$. Black stripedgranulitic apatitolite, yielding Tintinnids Eutintinnus tubulosus, Salpingella acuminata and Tubular fossils.

Bed $4 \quad 5.1 \mathrm{~m}$. Dark grey granulitite, yielding Tintinnids Eutintinnus tubulosus, Funnela sinensis, Tintinnopsis coronata, Salpingella acuminata and Tubular fossils.

Bed $3 \quad 0.2 \mathrm{~m}$. Striped granulitite, yielding Tintinnids Undella bicollaria, Xystonellopsis brandti and Tubular fossils. 


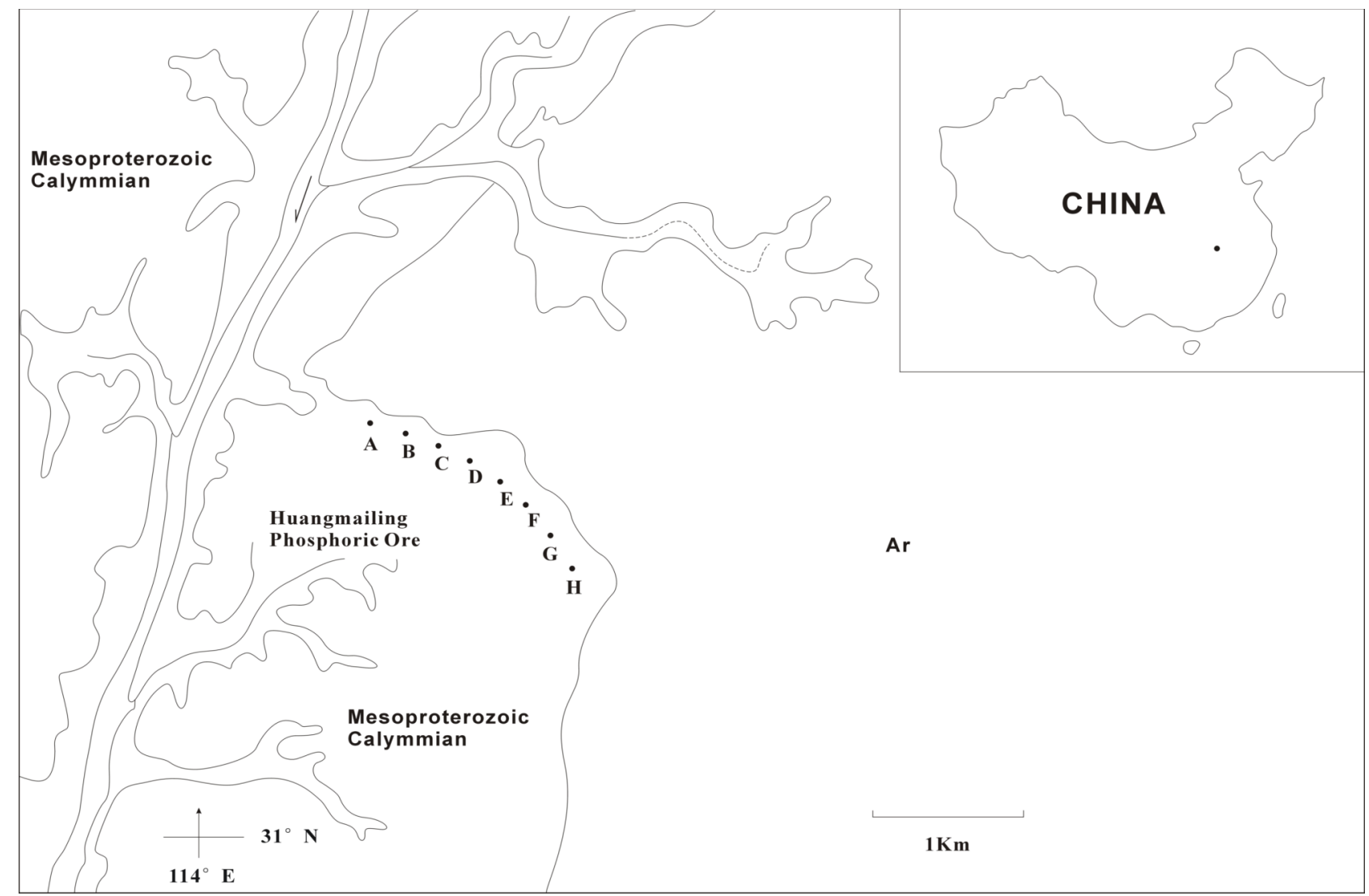

Fig. (1). Map showing location of ailing Phosphoric Ore, and all specimens discussed in this paper were found at localities A, B, C, D, E, F, $\mathbf{G}$ and $\mathbf{H}$.

Bed $2 \quad 2.7 \mathrm{~m}$. Grey leucoleptic apatitolite, yielding Tintinnids Eutintinnus frakmoi, Tintinnopsis coronata and Globule Sinosphaera hubeiensis and Tubular fossils.

Bed $1 \quad 0.45 \mathrm{~m}$. Black manganese apatitolite, yielding Globule Sinosphaera hubeiensis and Tubular fossils.

ヘnconformity

The underlying bed: grey archaeozoic era gneiss.

A total of eight Tintinnid species belong to six genera and four families were identified. They are Eutintinnus lusus-undae (Fig. 2), E. fraknoi (Fig. 9) and E. tubulosus (Fig. 3) of Genus Eutintinnus of Family Tintinnidae, and Funnela sinensis (Fig. 4) of Genus Funnela and Salpingella acuminata (Fig. 5) of Genus Salpingella of Tintinnidae too; Xystonellopsis brandti (Fig. 6) of Genus Xystonellopsis of Family Xystonellidae; Tintinnopsis coronata (Fig. 7) of Genus Tintinnopsis of Family Codonellidae; and Undella bicollaria (Fig. 8) of Genus Undella of Family Undellidae.

\section{EOECOLOGY}

All Tintinnid fossils are calcareous samples. The size of minerals, in gneiss, leucoleptic apatitolite, granulitite, granulitic apatitolite and leucoleptite of which contain Tintinnids, are from $0.02 \mathrm{~mm}$ to $0.3 \mathrm{~mm}$ in Huangmailing region. That is belong to the silt range. These rocks also contain the same size of pyrites. Tintinnids Xystonellopsis, Undella and Funnela were lived in Sea Basin or Deep under- water $[4,19]$. According to these above characters, we are sure that Tintinnids, from Huangmailing Phosphoric Ore of Central China, were lived in the sea basin of anoxic environment in Mesoproterozoic Calymmian.

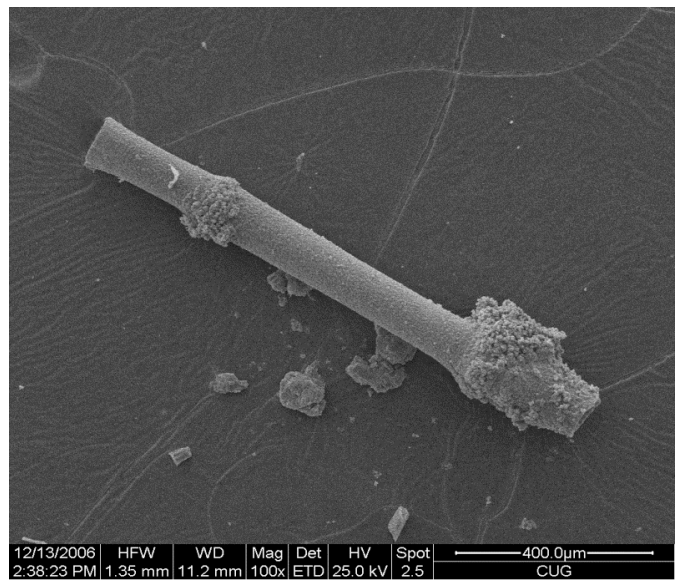

Fig. (2). Eutintinnus lusus-undae Entz, 1885. Fossil was collected from the ninth bed of granulitite of Section $\mathbf{D}$.

\section{CONCLUSION}

These six genera, Funnela, Eutintinnus, Salpingella, Xystonellopsis, Tintinnopsis and Undella, are the oldest ancestor of Tintinnids. They were lived in sea basin in Mesoproterozoic Calymmian at Huangmailing region of Hubei Province of Central China. Tintinnids had near 1600 million years history. 


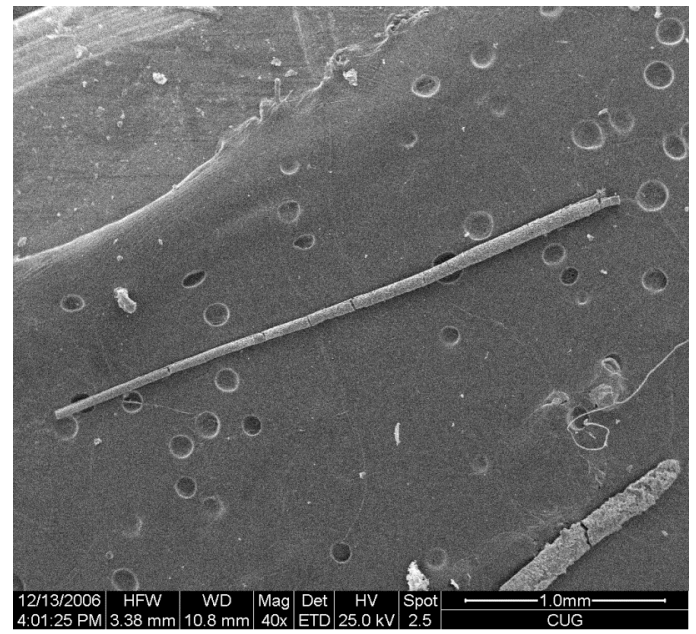

Fig. (3). Eutintinnus tubulosus (Ostenfeld) Kofoid \& Campbell 1939. Fossil was collected from the fourth bed of leucoleptite of Section G.

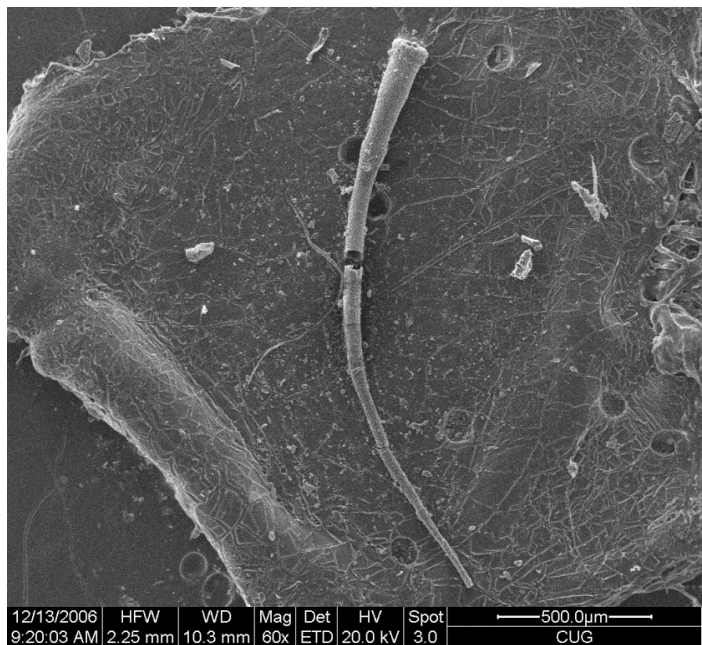

Fig. (4). Funnela sinensis Li \& Zhang, 2006. Fossil was Collected from the ninth bed of granulitic apatitolite of Section $\mathbf{G}$.

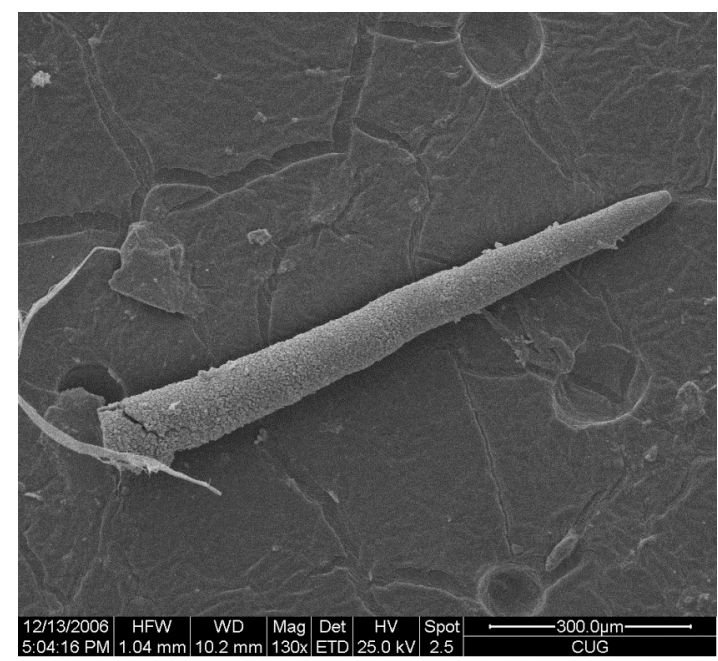

Fig. (5). Salpingella acuminata Kofoid \& Campbell, 1929. Fossil was collected from the fourth bed of leucoleptite of Section $\mathbf{G}$.

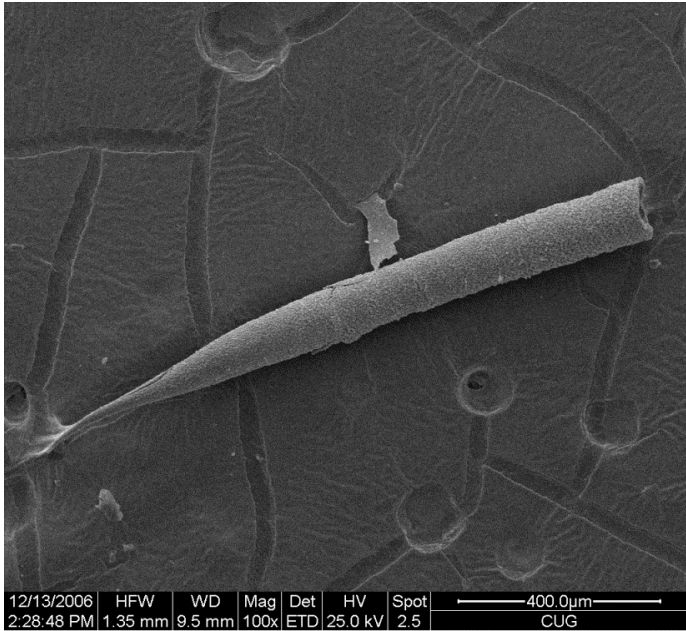

Fig. (6). Xystonellopsis brandti (Laackmann) Jörgensen, 1924. Fossil was collected from the fourth bed of leucoleptic apatitolite of Section $\mathbf{H}$.

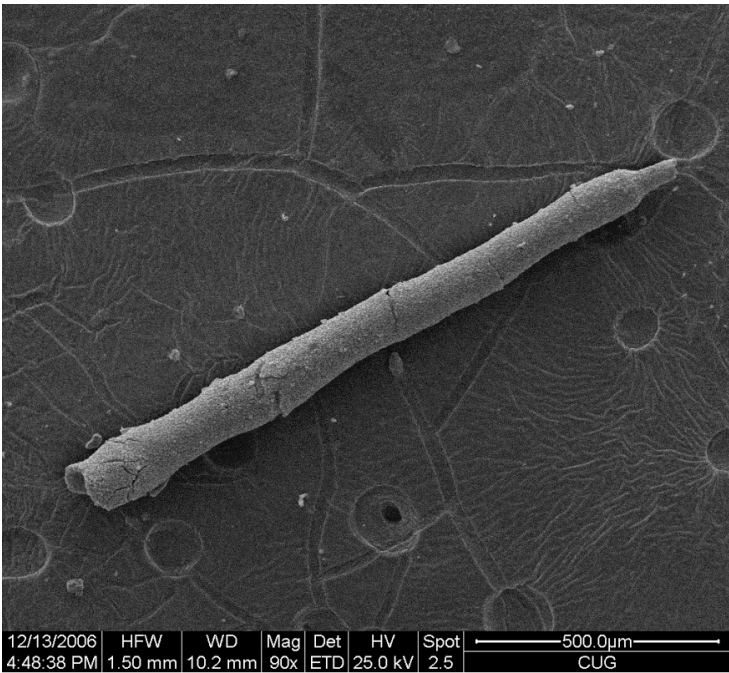

Fig. (7). Tintinnopsis coronata Kofoid \& Campbell, 1929. Fossil was collected from the fourth bed of leucoleptic apatitolite of Section $\mathbf{H}$.

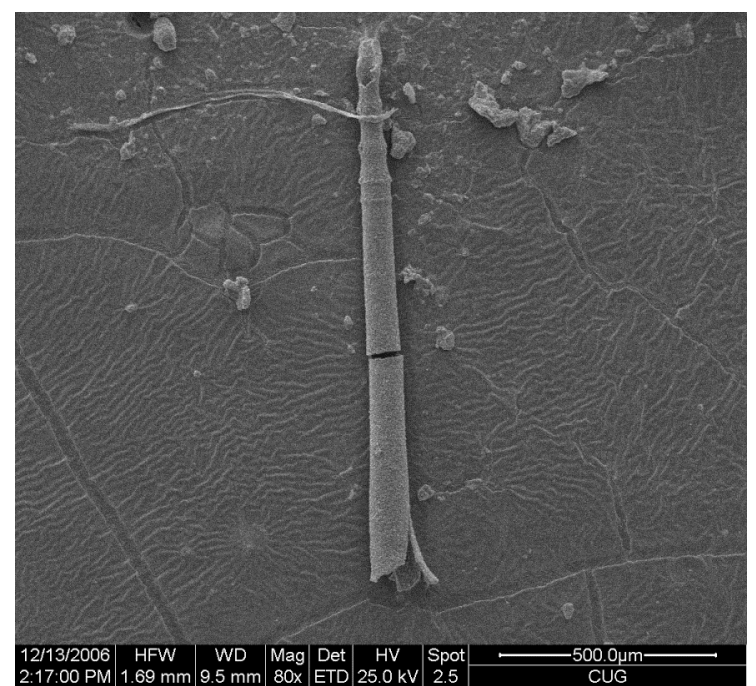

Fig. (8). Undella bicollaria Brandt, 1906. Fossil was collected from the ninth bed of granulitic apatitolite of Section $\mathbf{G}$. 


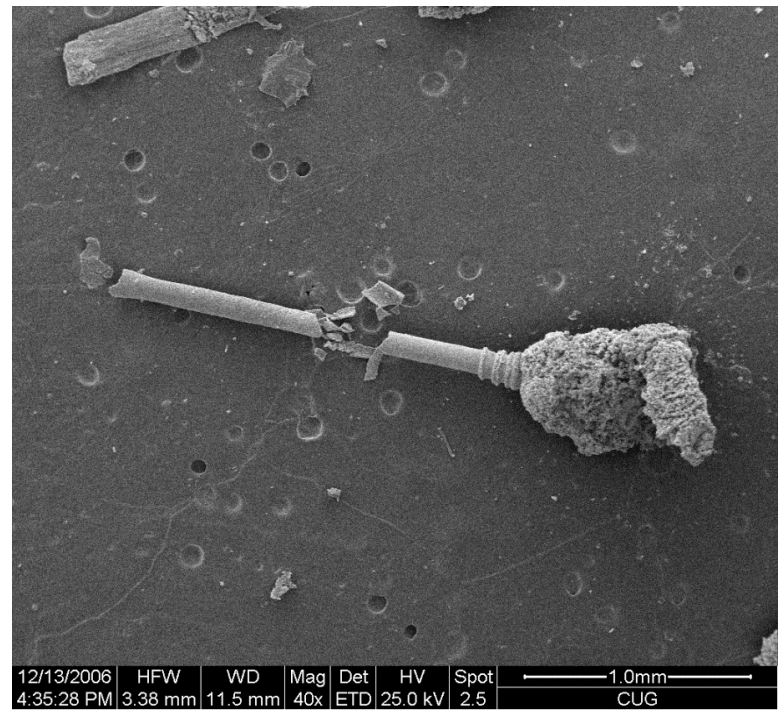

Fig. (9). Eutintinnus frakmoi (Daday) Kofoid \& Campbell, 1939. Fossil was collected from the ninth bed of granulitite of Section $\mathbf{D}$.

\section{ACKNOWLEDGEMENTS}

The research was carried out under the auspices of an award from the Key Laboratory of Biogeology and Environmental Geology (CUG), Ministry of Eduction. The field work in Huangmailing Phosphoric Ore was supplied by Engineer Ang Ren. Special thanks are due to Professor Jinnan Tong for he gave important information about the research.

\section{REFERENCES}

Kofoid CA, Campbell AS. A conspectus of the marine and freshwater ciliata belonging to the suborder Tintinnoinea, with descriptions of new species principally from the Agassiz expedition to the Eastern Tropical Pacific 1904-1905. Univ Calif Publ Zool 1929; 34: 1-403.

[2] Cariou JB, Dolan JR, Dallot S. A preliminary study of tintinnid diversity in the NW Mediterranean Sea. J Plankton Res 1999; 21: 1065-75.
[3] Verity PG. Grazing, respiration, excretion, and growth rates of tintinnids. Limnol Oceanogr 1985; 30(6): 1268-82.

[4] Kršinić F, Grbec B. Horizontal distribution of tintinnids in the Open waters of the Soyth Adriatic (Eastern Mediterranean). Sci Mar 2006; 70(1): 77-88.

[5] Gold K, Morales EA. Studies on the sizes, shapes, and the development of the lorica of agglutinated Tintinnida. Biol Bull 1976; 150(3): 377-92.

[6] Dolan JR. Re-discovered beauty-new images for old descriptionstropical tintinnids of the genus Xystonellopsis (Ciliophora, Tintinnia). Protist 2006; 157: 251-3.

[7] Dolan JR, Gallegos CL. Estuarine diversity of Tintinnids (Planktonic Ciliates). J Plankton Res 2001; 23(9): 1009-27.

[8] Davis CC. Variations of lorica shape in the genus Ptychocyis (Protozoa: Tintinnina) in relation to species identification. J Plankton Res 1981; 3(3): 433-43.

[9] Burns DA. The distribution and morphology of tintinnids (ciliate protozoans) from the costal waters around New Zealand. New Zealand J Mar Freshw Res 1983; 17: 387-406.

[10] Balkis N. Tintinnids (Protozoa cilophora) of the Büyükçekmece Bay in the Sea of Marmara. Sci Mar 2004; 68(1): 33-44.

[11] Dolan JR, Jacguet S, Torréton JP. Comparing taxonomic and morphological biodiversity of tintinnids (planktonic ciliates) of New Caledonia. Limnol Oceanogr 2006; 51(2): 950-8.

[12] Dolan JR, Ritchie ME, Ras J. The "Neutral" community structure of planktonic herbivores, tintinnid ciliates of the microzooplankton, across the SE tropical Pacific Ocean. Biogeosci Discuss 2007; 4 : 297-310

[13] Marshall SM. Protozoa. Zooplankton 1969; 117: 1-12.

[14] Eicher DL. Cretaceous tintinnids from the Western interior of the United States. Micropaleontology 1965; 11(4): 449-56.

[15] Colom G. Fossil tintinnids; loricated infusoria of the order of the Oligotricha. J Paleontol 1948; 22(2): 233-63.

[16] Moore RC. Treatise on Invertebrate Paleontology, Part D. Geological Society of America. New York: University of Kansas Press 1954; pp. 1-181.

[17] Porter SM, Knoll AH. Testate amoebae in the Neoproterozoic Era: evidence from vase-shaped microfossils in the Chuar Group, Grand Canyon. Paleobiology 2000; 26(3): 360-85.

[18] Li YX, Zhang SX. New material of microfossils from Middle Proterozoic in Hubei Province. Acta Palaeontol Sin 2006; 45(1): 102-7.

[19] Ling HY. Tintinnids: a taxon-vertical distributional study of settling assemblages from the Panama Basin. In: Honjo, Susumu, Ed. Ocean Biocoenosis Series, No. 4. Massachusetts: Woods Hole Oceanographic Institution 1992; pp. 1-21.

This is an open access article licensed under the terms of the Creative Commons Attribution Non-Commercial License (http://creativecommons.org/licenses/by$\mathrm{nc} / 3.0 /$ ) which permits unrestricted, non-commercial use, distribution and reproduction in any medium, provided the work is properly cited. 